\title{
Kesalahan Representasi Siswa dengan Kemampuan MatematikaTinggi dalam Menyelesaikan Masalah Perbandingan
}

\author{
Muhammad Galih Atmaja ${ }^{1}$, Tjang Daniel Chandra ${ }^{1}$, Swasono Rahardjo ${ }^{1}$ \\ ${ }^{1}$ Pendidikan Matematika-Universitas Negeri Malang
}

\begin{tabular}{l}
\hline INFO ARTIKEL \\
\hline Riwayat Artikel: \\
Diterima: $15-11-2019$ \\
Disetujui: $18-04-2020$ \\
\hline
\end{tabular}

\section{Kata kunci:}

misrepresentation;

mathematical ability;

ratio;

kesalahan representasi;

kemampuan matematika;

perbandingan

\begin{abstract}
ABSTRAK
Abstract: This study aims to describe the misrepresentation of students with high mathematical ability in solving comparative problems. This type of research is descriptive research. The subjects in this study were one grade VIII J student at SMP Negeri 1 Ngunut Tulungagung. In this study, data collection techniques used were tests to solve problems of comparison and interviews with students. Comparative test sheets and interview guidelines were used as instruments in this study. The results of this study are students with high mathematical ability to make visual and verbal representational errors at the step of understanding a problem. At the step of devising a plan, carrying out the plan and looking back the symbol representation error.
\end{abstract}

\begin{abstract}
Abstrak: Penelitian ini bertujuan untuk mendeskripsikan tentang kesalahan representasi siswa berkemampuan matematika tinggi dalam menyelesaikan masalah perbandingan. Jenis penelitian ini adalah penelitian deskriptif. Subjek dalam penelitian ini adalah satu siswa kelas VIII J di SMP Negeri 1 Ngunut Tulungagung. Dalam penelitian ini, teknik pengumpulan data yang digunakan adalah tes menyelesaikan masalah perbandingan dan wawancara dengan siswa. Lembar tes soal perbandingan dan pedoman wawancara digunakan sebagai instrumen dalam penelitian ini. Hasil penelitian ini adalah siswa yang berkemampuan matematika tinggi melakukan kesalahan representasi visual dan verbal pada tahap memahami masalah. Pada tahap merencanakan penyelesaian, melaksanakan rencana penyelesaian dan memeriksa kembali melakukan kesalahan representasi simbol.
\end{abstract}

\section{Alamat Korespondensi:}

Muhammad Galih Atmaja

Pendidikan Matematika

Universitas Negeri Malang

Jalan Semarang 5 Malang

E-mail: galihatmaja98@gmail.com
Matematika adalah salah satu bidang studi yang diberikan pada setiap tingkatan pendidikan. Matematika sangat berperan penting dalam kehidupan sehari-hari dan dalam upaya penguasaan ilmu pengetahuan (Matic, 2014; Rohmah \& Sutiarso, 2018). Selain itu, Cockcroft (1982) berpendapat bahwa: "Siswa harus mendapat pelajaran matematika karena (1) selalu berguna dalam kehidupan, (2) semua segi kehidupan membutuhkan kecakapan matematika yang tepat, (3) adalah media komunikasi yang ringkas dan jelas, (4) berguna untuk mempresentasikan informasi dalam berbagai cara, dan (5) memberikan kepuasan untuk mencoba menyelesaikan masalah yang sulit dipecahkan. Dalam proses pembelajaran matematika, siswa diminta mengembangkan cara berpikir mereka dalam menyelesaikan suatu permasalahan matematika (Karp, 2010). Pemecahan masalah adalah salah satu hal yang terpenting dalam proses belajar mengajar matematika (Pantziara, Gagatsis, \& Elia, 2009). (Polya, 1985) mendefinisikan pemecahan masalah merupakan suatu cara menemukan solusi dari suatu kesulitan untuk menggapai tujuan secara tidak langsung. Pekerjaan utama guru matematika adalah mencurahkan kemampuannya untuk menumbuhkan kemampuan siswa dalam memecahkan masalah (Baxter \& Williams, 2010; Shreyar, Zolkower, \& Pérez, 2010).

Tahap-tahap penyelesaian masalah berpedoman pada tahap pemecahan masalah yang dinyatakan oleh Polya, yaitu (1) memahami permasalahan, (2) merencanakan penyelesaian, (3) melaksanakan rencana penyelesaian, dan (4) memeriksa jawaban yang diperoleh. Sebelum siswa menyelesaikan permasalahan tersebut, siswa harus mampu memahami permasalahan. Untuk memahami permasalahan tersebut maka siswa harus merepresentasikan gagasan yang diketahui dalam persoalan yang sedang dikerjakan. Dengan demikian, siswa dapat merencanakan penyelesaian masalah tersebut setelah merepresentasikan ide-ide matematika yang ada dalam permasalahan. Montague (dalam Fadillah, 2010) menegaskan bahwa tanpa representasi masalah yang cocok, maka pemecahan masalah tidak mungkin akan berhasil. Siswa pasti akan merasa kesulitan dalam pemecahan masalah jika ia merasa sulit dalam merepresentasikan persoalan matematika. 
Berdasarkan NCTM (2000) representasi merupakan kunci pokok atau sentral untuk mempelajari matematika. Representasi yang ditampilkan oleh siswa adalah ungkapan dari gagasan matematika siswa dengan maksuduntuk mencari solusi dari persoalan yang dihadapi. Menurut Supandi, Waluya, Rochmad, Suyitno, \& Dewi (2018) representasi matematika berperan dalam meningkatkan pemahaman konsep matematika dan memecahkan masalah matematika siswa. Representasi dapat dikatakan sebagai alat untuk mengomunikasikan, menguatkan, dan menalar suatu ide untuk dirinya sendiri maupun untuk orang lain. Goldin \& Steingold (2001) menyebutkan bahwa "A representation is typically a sign or configuration of sign, characters, or object. The important things is it can stand for (symbolize, depict, encode, or represent) something other than itself”, yang berarti representasi adalah bentuk yang dapat melukiskan objek yang diamati dalam bentuk yang lain. Kegiatan representasi ini dapat menunjukkan pemahaman siswa mengenai objek yang diamati. Kalathil \& Sherin (2000) menyatakan representasi siswa sebagai sesuatu yang dibuat oleh siswa untuk mengeluarkan dan memperlihatkan ide mereka kepada orang lain.Goldin \& Steingold(2001)menyebutkan bahwa representasi dibagi menjadi dua sistem, yaitu sistem internal dan sistem eksternal. Representasi internal adalah suatu bentuk mental individu yang secara langsung tidak dapat dilihat, tetapi dapat diketahui dengan mengobservasi perilaku matematika.

Representasi eksternal merupakan wujud atau bentuk dari representasi internal yang dapat diamati, misalnya dalam bentuk penulisan dengan kata-kata, grafik, angka, atau aljabar. Jenis-jenis representasi eksternal, meliputi (1) representasi verbal adalah representasi dinyatakan dalam tulisan atau kata-kata; (2) representasi visual yaitu termasuk gambar, diagram atau grafik, serta beberapa kegiatan yang saling terkait; (3) representasi simbol yaitu terdiri dari persamaan, tanda operasi dan koneksi, simbol aljabar dan beberapa tindakan yang saling berhubungan (Hwang, Chen, Dung, \& Yang, 2007; Castellanos, Castro, \& Gutiérrez, 2009). NCTM (2000) menegaskan standar representasi untuk kegiatan belajar mengajar dari sebelum taman kanakkanak sampai kelas dua belas adalah representasi harus mengizinkan siswa untuk: (1) membangun dan memanfaatkan representasi untuk mengenal, menulis, dan menghubungkangagasan matematika, (2) memilah, menggunakan, dan melakukan translasi antar representasi matematis untuk menyelesaikan suatupersoalan, dan (3) menerapkan representasi untuk menafsirkan kejadian fisik, sosial, dan fenomena matematika. Berdasarkan uraian di atas, representasi diartikan sebagai perwujudan atau bentuk yang dapat menggambarkan ide matematis dari suatu permasalahan sebagai hasil pemahaman siswa. Jenis representasi yang dipakai dalam penelitian ini adalah representasi eksternal yaitu visual, simbolik, dan verbal (kata-kata). Kemampuan representasi matematis tersebut dapat dilihat melalui indikator kemampuan representasi matematis. Indikator kemampuan representasi yang diadopsi dari Mudzakir (2006) sebagaimana ditunjukkan pada tabel 1.

Tabel 1. Indikator Kemampuan Representasi Matematis

\begin{tabular}{clll}
\hline No & \multicolumn{1}{c}{ Representasi } & & \multicolumn{1}{c}{ Bentuk-Bentuk Operasional } \\
\hline 1. & Visual & $\bullet$ & $\begin{array}{l}\text { Siswa dapat membuat gambar atau tabel untuk mempermudah masalah serta membantu } \\
\text { dalam menyelesaikannya. }\end{array}$ \\
2. $\begin{array}{l}\text { Persamaan atau ekspresi matematis } \\
\text { (simbolik) }\end{array}$ & $\bullet \quad$ Siswa dapat membuat model matematika. \\
& $\bullet \quad$ Siswa dapat menyelesaikan masalah dengan ekspresi matematis. \\
3. $\begin{array}{l}\text { Kata-kata atau teks tertulis } \\
\text { (verbal) }\end{array}$ & $\bullet \quad$ Siswa dapat mengubah kalimat yang diketahui pada soal menjadi kalimat yang setara. \\
\hline
\end{tabular}

Berdasarkan studi pendahuluan yang peneliti lakukan di SMP Negeri 1 Ngunut Tulungagung, siswa yang melakukan kesalahan dalam menyelesaikan masalah perbandingan masih banyak. Konsep perbandingan dipandang sebagai materi prasyarat matematika yang penting dan harus dipahami dengan baik karena konsep perbandingan digunakan untuk menghitung skala yang digunakan pada peta, menghitung luas juring pada materi lingkaran atau menghitung sisi segitiga pada teorema Pythagoras. Selain itu, penerapan materi perbandingan sering digunakan dalam kehidupan sehari-hari misalnya komposisi perbandingan tepung terigu, gula pasir, telur, dan air untuk membuat roti. Peneliti memberikan dua masalah perbandingan kepada 32 siswa. Dari 32 siswa yang diberikan masalah perbandingan, terdapat 24 siswa yang masih salah dalam menyelesaikan masalah nomor 1 dan 8 siswa benar dalam menyelesaikan masalah tersebut. Dari delapan siswa ini termasuk siswa yang memiliki kemampuan matematika tinggi menurut informasi yang didapatkan dari guru matematika. Hal ini menerangkan bahwa ada $75 \%$ siswa yang masih salah dalam menyelesaikan masalah. Ketika menyelesaikan masalah tersebut siswa melakukan kesalahan representasi simbol dalam merepresentasikan rumus untuk mencari jarak sebenarnya. Salah satu siswa menuliskan rumus mencari jarak sebenarnya yaitu $j s=s \times j p$. Ini menegaskan bahwa siswa masih belum mengerti konsep skala. Seharusnya untuk mencari jarak sebenarnya dapat diperoleh dengan membagi jarak pada peta dengan skala dan biasa dirumuskan:js $=\frac{j p}{s}$.

Untuk masalah nomor dua, tidak terdapat siswa yang menyelesaikan masalah tersebut dengan benar. Ini menerangkan bahwa seluruh siswa salah dalam menyelesaikan masalah nomor dua, termasuk siswa yang berkemampuan matematika tinggi dengan kriteria apabila memiliki nilai ulangan harian antara 90 dan 100. Kesalahan yang dilakukan oleh siswa bukanlah sesuatu yang harus dihindari karena dari kesalahan guru dapat mengetahui seberapa pemahaman siswa terhadap pembelajarandi kelas 
dan juga menjadi bekal guru untuk memberikan bantuan kepada siswa serta bekal untuk memperbaiki pembelajaran pada pertemuan selanjutnya (Lannin, Barker, \& Townsend, 2007). Kesalahan siswa saat menyelesaikan suatu persoalan ini perlu dianalisis. Arnidha (2015) mengungkapkan bahwa kegiatan analisis terhadap kesalahan yang dilakukan siswa ini bertujuan untuk menentukan jenis dan penyebab kesalahan tersebut.

\section{METODE}

Jenis penelitian ini merupakan penelitian deskriptif. Data yang dihasilkan berupa kalimat dalam bentuk lisan maupun tertulis. Data yang berupa ucapan (lisan) diperoleh dari hasil wawancara dengan siswa, sedangkan data berupa tulisan diperoleh dari pekerjaan siswa. Oleh sebab itu, penelitian ini adalah penelitian kualitatif. Penelitian ini memenuhi ciri-ciri penelitian kualitatif yang dinyatakan oleh Cresswell (2012), yaitu (1) peneliti mengumpulkan data di lokasi penelitian terkait masalah yang diteliti, (2) kajian teori dalam penelitian ini berperan memberikan alasan permasalahan, (3) peneliti mengumpulkan data dari beberapa sumber seperti hasil pengamatan (observasi), hasil wawancara, dan hasil pekerjaan siswa, (4) peneliti menganalisis data dan mendeskripsikannya dalam bentuk kata-kata, (5) peneliti menuliskan laporan hasil penelitian secara fleksibel, terstruktur dan sesuai dengan kriteria evaluasi.Penelitian ini memiliki tujuan untuk mendeskripsikan tentang kesalahan representasi siswa berkemampuan matematika tinggi dalam pemecahan masalah perbandingan. Penelitian dilakukan di SMP Negeri 1 Ngunut Tulungagung kelas VIII J berjumlah 32 siswa, terdiri 19 siswa (59,38\%) laki-laki dan 13 siswa (40,62\%) perempuan. Kemudian 32 siswa tersebut dipilih satu siswa berkemampuan matematika tinggi yang masih melakukan kesalahan representasi dalam menyelesaikan masalah perbandingan dan selanjutnya disebut sebagai subjek 1 (S1). Instrumen penelitian ini menggunakan tes soal perbandingan dan pedoman wawancara. Lembar soal perbandingan dan pedoman wawancara tersebut divalidasi oleh seorang dosen pendidikan matematika dan seorang guru matematika. Tes soal perbandingan dibuat berupa soal cerita yang terdiri dari 2 item sebagai berikut:

1. Suatu peta berskala 1:12.000.000. Jarak kota Nganjuk dan kota Banyuwangi pada peta adalah $3 \mathrm{~cm}$. Rombongan siswa SMP Pelita Bangsa dengan menaiki bus berangkat dari kota Nganjuk menuju kota Banyuwangi pada pukul 06.15 dengan kecepatan rata-rata bus $80 \mathrm{~km}$ per jam untuk rekreasi. Selama perjalanan bus berhenti istirahat sebanyak 1 kali selama 35 menit. Pukul berapa mereka tiba di kota Banyuwangi? Berikan penjelasannya!

2. Suatu proyek pembangunan rumah direncanakan selesai selama 50 hari dengan pekerja 20 orang. Pada hari ke-20, pekerjaan diberhentikan selama enam hari disebabkan kehabisan bahan baku. Jika kemampuan bekerja setiap orang sama dan pekerjaan harus selesai tepat waktu, berapa tambahan pekerja yang dibutuhkan? Berikan penjelasannya!

Sumber data penelitian ini merupakan siswa kelas VIII J SMP Negeri 1 Ngunut Tulungagung yaitu1 siswa berkemampuan matematika tinggi yang melakukan kesalahan representasi dalam menyelesaikan masalah matematika saat diberikan tes dan mampu berkomunikasi dengan baik saat mengungkapkan pemikirannya. Deskripsi data ini akan ditampilkan dalam bentuk teks naratif. Data tersebut dikumpulkan berdasarkanhasil jawaban siswa dan hasil wawancara yang nantinya akan dianalisis. Analisis data adalah kegiatan penyusunan data penelitian dengan sistematis, baik data berdasarkan hasil tes maupun data dokumentasi. Data disusun dengan memilih data yang penting kemudian dianalisis untuk memperoleh suatu kesimpulan agar mudah dimengerti. Miles dan Huberman (dalam Sugiyono, 2012) menyatakan bahwa teknik analisis data pada penelitian kualitatif dilakukan dengan tahap mereduksi data, menyajikan data, dan menarik simpulan.

\section{HASIL}

Pada masalah nomor 1, S1 dapat menuliskan informasi yang diketahui dan ditanyakan pada langkah memahami masalah.

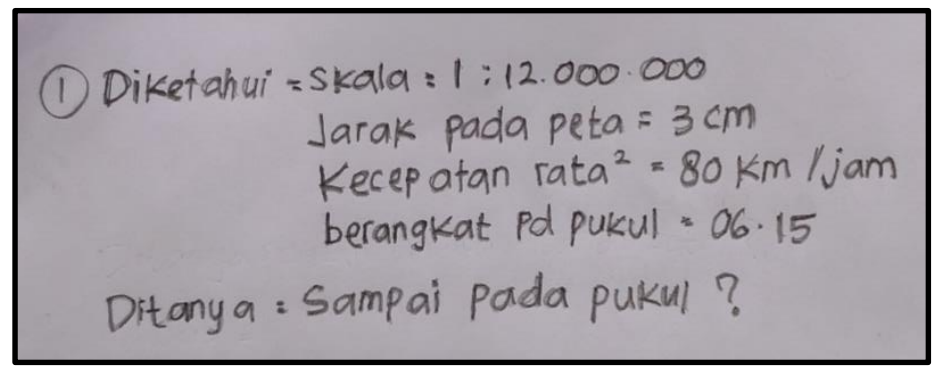

Gambar 1. Hasil Pekerjaan S1 pada Tahap Memahami Masalah 1

Pada gambar 1 terlihat S1 menuliskan diketahui: skala $=1: 12.000 .000$, jarak pada peta $=3 \mathrm{~cm}$, kecepatan rata-rata $=80$ $\mathrm{km} / \mathrm{jam}$, berangkat pukul $=06.15$, kemudian yang dicari adalah waktu tiba bus. S1 melakukan kesalahan representasi verbal ketika menulis informasi yang diketahui. S1 tidak menulis waktu istirahat satu kali selama 35 menit. 


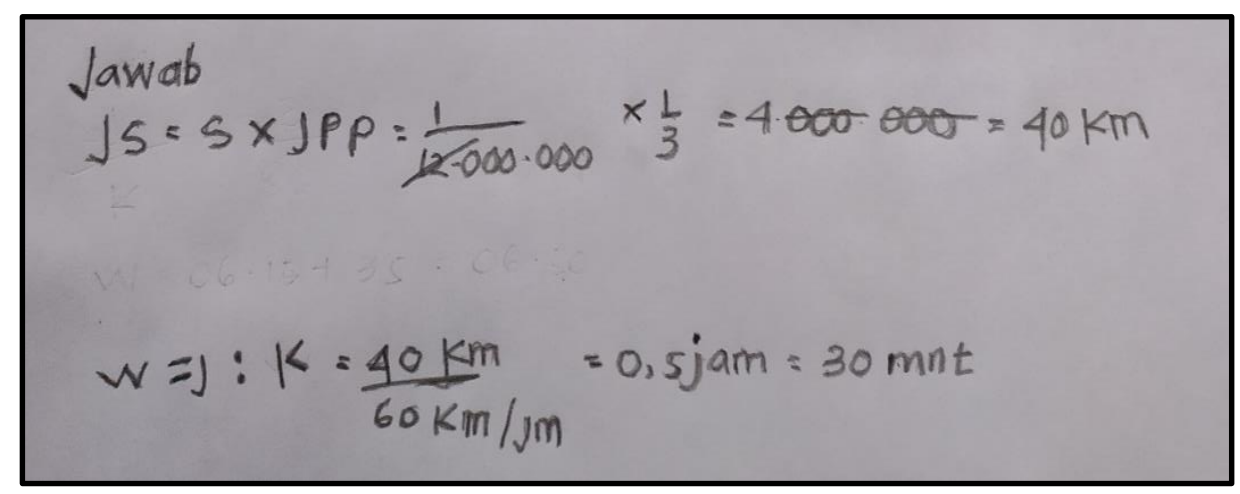

Gambar 2. Hasil Pekerjaan S1 pada Tahap Merencanakan Penyelesaian Masalah 1

Pada langkah membuat rencana penyelesaian yang terlihat pada gambar 2 , S1 menuliskan $J S=S \times J P P$. Simbol “JS” memiliki arti jarak sebenarnya antara kota Nganjuk dan kota Banyuwangi. Simbol " $S$ " memiliki arti skala yang dipakai pada peta. Simbol "JPP” memiliki arti jarak kota Nganjuk dan kota Banyuwangi pada peta. Kemudian $\mathrm{S} 1$ menuliskan $W=J: K$. Simbol " $W$ " memiliki arti waktu yang ditempuh bus. Simbol " $J$ " memiliki arti jarak kota Nganjuk dan kota Banyuwangi. Simbol " $K$ " memiliki arti kecepatan rata-rata bus. Kesalahan representasi simbol yang dilakukan oleh S1 adalah ketika ia menuliskan $J S=S \times J P P$. Berdasarkan konsep yang diketahui siswa, bahwa skala merupakan perbandingan antara jarak yang terdapat di peta dengan jarak sebenarnya, maka dapat ditulis $S=\frac{J P P}{J S}$. Sehingga untuk mencari jarak sebenarnya yang benar adalah $J S=\frac{J P P}{S}$.

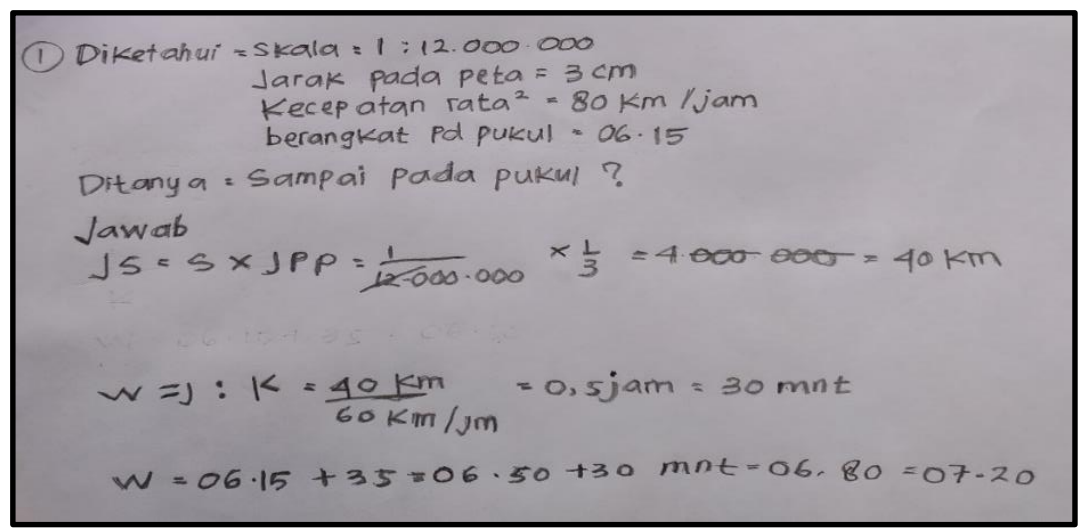

Gambar 3. Hasil Pekerjaan S1 pada Tahap Melaksanakan Rencana

\section{Penyelesaian Masalah 1}

Pada langkah melaksanakan rencana penyelesaian yang terlihat pada Gambar 3, S1 telah memasukkan apa yang diketahui ke dalam rumus jarak sebenarnya yaitu $J S=S \times J P P=\frac{1}{12.000 .000} \times \frac{1}{3}=4.000 .000=40 \mathrm{~km}$. Kesalahan representasi simbol yang dilakukan S1 adalah ketika menuliskan jarak kota Nganjuk dan Banyuwangi pada peta adalah $\frac{1}{3}$. Padahal yang diketahui dalam soal, jarak kota Nganjuk dan Banyuwangi di peta adalah $3 \mathrm{~cm}$. Selain itu, S1 juga melakukan kesalahan representasi simbol ketika menuliskan $\frac{1}{12.000 .000} \times \frac{1}{3}=4.000 .000$. Walaupun begitu jawaban S1 tetap salah karena konsep yang digunakan untuk mencari jarak kedua kota sebenarnya juga salah. Selain itu kesalahan representasi simbol yang dilakukan $\mathrm{S} 1$ adalah ketika mencari waktu tempuh bus, yaitu $W=J: K=\frac{40 \mathrm{~km}}{60 \mathrm{~km} / \mathrm{jm}}=0,5 \mathrm{jam}=30 \mathrm{mnt}$. S1 melakukan kesalahan representasi simbol ketika menuliskan kecepatan rata-rata bus adalah $60 \mathrm{~km} / \mathrm{jam}$, padahal dalam soal kecepatan ratarata bus adalah $80 \mathrm{~km} / \mathrm{jam}$. Selain itu S1 melakukan kesalahan perhitungan dalam membagi $\frac{40 \mathrm{~km}}{60 \mathrm{~km} / \mathrm{jm}}=0,5 \mathrm{jam}$. 


\section{$W=06 \cdot 15+35=06 \cdot 50+30 m n t=06 \cdot 80=07 \cdot 20$}

\section{Gambar 4. Hasil Pekerjaan S1 ketika Mencari Waktu Tiba Bus}

Setelah menemukan jarak sebenarnya kedua kota, kemudian menemukan waktu tempuh bus, kemudian S1 mencari waktu bus tiba di tujuan dengan menambahkan semua dari waktu bus berangkat, waktu istirahat, dan waktu tempuh bus seperti terlihat pada Gambar4. S1 menuliskan $W=06.15+35=06.50+30$ mnt $=06.80=07.20$. Kesalahan representasi simbol yang dilakukan $\mathrm{S} 1$ adalah saat ia menuliskan $06.15+35=06.50$. Seharusnya yang benar adalah $W=06.15+35$ menit $=$ 06.50, karena itu menunjukkan menit. Selain itu, S1 tidak menuliskan kesimpulan pada permasalahan tersebut. Oleh karena itu, S1 melakukan kesalahan representasi simbol pada langkah memeriksa jawaban yang didapatkan. Pada permasalahan yang kedua, S2 tidak menulis informasi yang diketahui dan ditanyakan pada soal. Dia langsung menggambarkan sebuah tabel seperti pada gambar 5 .

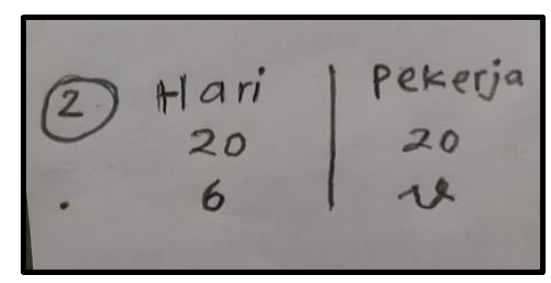

\section{Gambar 5. Hasil Pekerjaan S1 pada Tahap Memahami Masalah 2}

Pada gambar 5, S1 menuliskan pada baris pertama kolom "hari” adalah 20 dan kolom "pekerja” adalah 20. Selanjutnya pada baris kedua menuliskan kolom "hari" adalah 6 dan kolom "pekerja" adalah $x$. Simbol " $x$ " memiliki arti banyak pekerja yang dibutuhkan selama 6 hari. Kesalahan representasi visual yang dilakukan S1 adalah ketika menuliskan pada kolom "hari" adalah 20. Padahal yang diketahui dalam soal bahwa pembangunan selesai selama 50 hari dan jumlah pekerja 20 orang. Selain itu kesalahan representasi visual S1 adalah menuliskan pada kolom "hari" adalah 6 dan pada kolom "pekerja" adalah $x$. Padahal dalam soal diketahui bahwa 6 hari itu adalah lama pekerjaan terhenti. Seharusnya ia menuliskan kalkulasi sisa waktu pekerjaan $50-20-6=24$ hari.

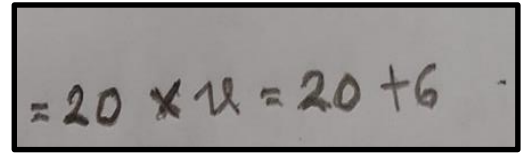

\section{Gambar 6. Hasil Pekerjaan S1 pada Tahap Merencanakan Penyelesaian Masalah 2}

Pada langkah membuat rencana penyelesaian yang terlihat pada gambar 6 , S1 menuliskan $20 \times x=20+6$. Kesalahan representasi simbol yang dilakukan S1 adalah menuliskan $20+6$. Seharusnya operasi yang benar adalah perkalian bukan penjumlahan. Walaupun begitu jawaban S1 tetap salah karena tidak sesuai dengan konsep perbandingan berbalik nilai dan salah dalam menulis informasi yang diketahui dalam tabel.

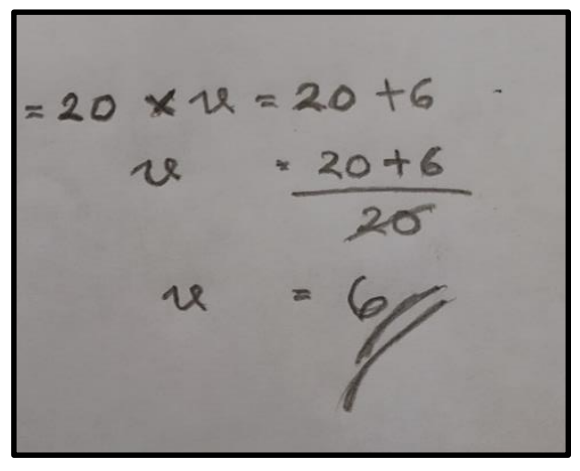

Gambar 7. Hasil Pekerjaan S1 pada Tahap Melaksanakan Rencana Penyelesaian Masalah 2 
Pada tahap melaksanakan rencana penyelesaian yang terlihat pada Gambar 7 , S1 menuliskan $20 \times x=20+$ 6. Kemudian $x=\frac{20+6}{20}$. Setelah itu $x=6$. Kesalahan representasi simbol yang dilakukan S1 adalah menuliskan operasi penjumlahan pada $x=\frac{20+6}{20}$. Seharusnya operasinya adalah perkalian.

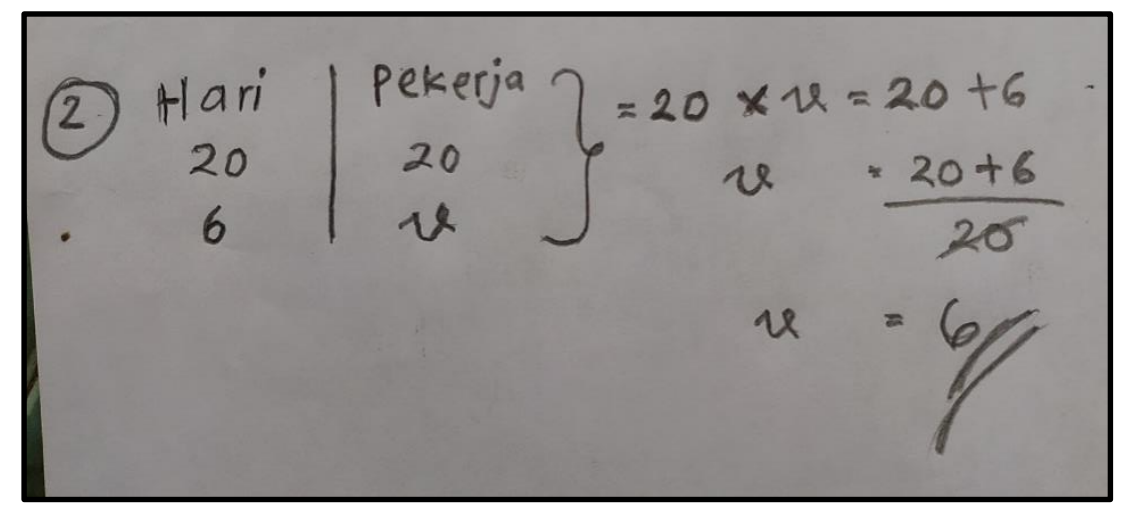

Gambar 8. Hasil Pekerjaan S1 ketika Mencari Tambahan Pekerja yang Dibutuhkan

Setelah memanipulasi persamaan yang dibuat, akhirnya menemukan $x=6$. Simbol " $x$ ” berarti jumlah pekerja untuk menyelesaikan pekerjaan. Padahal dalam soal yang ditanyakan adalah banyak pekerja tambahan yang dibutuhkan. Jadi S1 tidak menjawab sesuai dengan pertanyaan yang diberikan. Selain itu S1 tidak menuliskan kesimpulan pada permasalahan tersebut. Oleh karena itu, S1 melakukan kesalahan representasi simbol pada tahap memeriksa jawaban yang didapatkan.

\section{PEMBAHASAN}

Berdasarkan hasil penelitian diperoleh siswa yang memiliki kemampuan matematika tinggi menerapkan representasi visual, verbal, dan simbol untuk menyelesaikan permasalahan. Pada langkah memahami masalah, siswa dituntut untuk dapat menulis informasi yang diketahui dan ditanyakan dalam permasalahan. Namun, hal ini tidak sepenuhnya dapat dilakukan dengan baik oleh siswa. Ini terbukti ketika subjek penelitian tidak dapat menulis segala informasi pokok yang terdapat dalam permasalahan. Pada permasalahan nomor 1, S1 yang memiliki kemampuan matematika tinggi tidak menulis dengan lengkap informasi yang diketahui dalam permasalahan. S1 menulis skala $=1: 12.000 .000$, jarak pada peta $=3 \mathrm{~cm}$, kecepatan rata - rata $=$ $80 \mathrm{~km} / \mathrm{jam}$, berangkat pukul = 06.15. Kesalahan representasi verbal yang S1 lakukan adalah tidak menuliskan informasi penting lainnya yaitu bus istirahat satu kali selama 35 menit. Hal ini didukung oleh penelitian Musdhalifah, Sutinah, \& Kurniasari (2013) yang menegaskan bahwa kesalahan siswa berkemampuan matematika tinggi kurang lengkap menulis informasi yang diketahui pada tahap memahami masalah. Lebih lanjut, Rindyana (2012) mengungkapkan bahwa ketika menyelesaikan soal cerita beberapa kesalahan yang dilakukan siswa yaitu tidak menuliskan informasi dengan lengkap. Penyebab kesalahan representasi ini adalah siswa terbiasa menyelesaikan permasalahan tanpa menulis hal yang diketahui.

Pada permasalahan nomor dua, S1 tidak dapat menulis hal yang diketahui pada soal dengan benar. S1 melakukan kesalahan representasi visual ketika menggambar tabel dan menuliskan pada baris pertama kolom "hari" adalah 20 dan kolom "pekerja" adalah 20. Pada baris kedua menuliskan pada kolom "hari" adalah 6 dan kolom "pekerja" adalah $x$. S1 juga tidak menulis hal yang ditanyakan dalam permasalahan. Kesalahan representasi visual yang dialamisubjek tersebut disebabkan karena kurangnya pemahaman maksud soal. Berdasarkan hasil penelitian tersebut menunjukkan subjek masih mengalami kesulitan untuk menulis informasi yang diketahui maupun ditanyakan pada soal serta kesulitan dalam menyelesaikan masalah nomor 2 . Hal ini sejalan dengan penelitian Rahayu, Muhsetyo, \& Rahardjo (2016) mengungkapkan bahwa sulitnya siswa dalam memahami masalah mengakibatkan siswa sulit untukmenyebutkan pertanyaan dan informasiyang digunakandalam menyelesaikan permasalahan tersebut. Lebih lanjut Tambychik \& Meerah (2010) dalam penelitiannya menyatakan bahwa beberapa siswa gagal dalam memahami masalah disebabkan tidak memahami pertanyaan soal dan banyaknya informasi yang ada membuat siswa bingung tentang fokus permasalahan. Oleh karena itu, siswa mengalami kesalahan dalam memahami masalah.

Tahap selanjutnya dalam langkah pemecahan masalah Polya adalah merencanakan penyelesaian. Pada tahap ini langkah yang dilakukan adalah mengkonstruksi strategi pemecahan masalah yang akan dilakukan serta membuat model matematika dari rancangan strategi penyelesaian yang telah dilakukan. Subjek penelitian telah melakukan tahap merencanakan penyelesaian tetapi masih melakukan kesalahan representasi. Pada masalah nomor 1, S1 melakukan kesalahan representasi simbol ketika menuliskan rumus mencari jarak sebenarnya kota Nganjuk dan Banyuwangi $J S=S \times J P P$. Pada masalah nomor 2, S1 melakukan kesalahan representasi simbol ketika menuliskan persamaan $20 \times x=20+6$. Dari uraian tersebut, S1 tidak menggunakan konsep perbandingan berbalik nilai dengan benar. Kesalahan S1 tersebut dalam menentukan strategi penyelesaian menyebabkan tidak terselesaikannya pekerjaan siswa dan hasil yang diperoleh juga salah. Hal ini sejalan dengan penelitian 
Barake, Naim, \& Juhaina (2015) bahwa kesulitan siswa dalam merencanakan penyelesaian permasalahan mengakibatkan tidak lengkapnya jawaban yang diperoleh dan hasil yang salah karena siswa tidak mengerti cara melanjutkan proses penyelesaiannya. (Liang, 2013; Jupri, Drijvers, \& Van den Heuvel-Panhuizen, 2014) juga mengungkapkan bahwa siswa kebanyakan tidak memiliki alur penyelesaian yang runtut, hal ini dikarenakan pemahaman siswa yang tidak lengkap. Lebih lanjut (Buaddin, 2015) mengungkapkan bahwa ketidakmampuan siswa dalam merencanakan penyelesaian berdasarkan apa yang diketahui dan ditanyakan dalam permasalahan menyebabkan siswa sulit untuk menyusun suatu strategi penyelesaian. Prakitipong \& Nakamura (2006) menambahkan bahwa siswa mengalami kesalahan karena tidak mampu memaknai pertanyaan untuk rumus yang tepat dalam menyelesaikan suatu masalah.

Tahap ketiga dari langkah pemecahan Polya adalah melaksanakan rencana penyelesaian. Kegiatan yang dilakukan pada langkah ini adalah menyatakan hubungan rencana penyelesaian permasalahan dengan konsep matematika secara tertulis serta memanipulasi model matematika. Selain itu, hal lain yang dilihat dari tahapan pelaksanaaan rencana penyelesaian ini adalah subjek harus dapat menyelesaikan masalah tersebut menggunakan langkah penyelesaian yang sistematis dan terampil dalam algoritma serta ketepatan jawabannya. Pada tahap ini siswa melakukan kesalahan representasi simbol dalam memanipulasi model matematika. Pada persoalan nomor satu, kesalahan representasi simbol yang dilakukan $\mathrm{S} 1$ adalah menulis $J S=S \times$ $J P P=\frac{1}{12.000 .000} \times \frac{1}{3}=4.000 .000=40 \mathrm{~km}$. Selain itu kesalahan $\mathrm{S} 1$ adalah menuliskan $W=J: K=\frac{40 \mathrm{~km}}{60 \mathrm{~km} / \mathrm{jm}}=0,5 \mathrm{jam}=$ 30 mnt, padahal dalam soal diketahui kecepatan rata-rata bus adalah $80 \mathrm{~km} / \mathrm{jam}$. Kesalahan representasi simbol yang dilakukan oleh S1 disebabkan karena kurang teliti dalam merepresentasikan informasi yang diketahui dari permasalahan. Hal ini sesuai dengan penelitian Widodo (2013) menjelaskan bahwa kesalahan siswa dalam menggunakan simbol berhubungan dengan kekurangcermatan siswa terkait dengan simbol-simbol matematika. Pada masalah nomor 2, S1 dapat menuliskan bentuk persamaan. Walaupun S1 menggunakan bentuk persamaan sebagai model matematika dari masalah nomor 2, namun bentuk persamaan tersebut tidak sesuai dengan masalah. S1 salah menuliskan model matematika yaitu $20 \times x=20+6$. Subjek mengaku tidak mengerti dan hanya menebak saja dalam menyelesaikan masalah tersebut. Kesalahan konsep dan pengerjaan asal-asalan yang dilakukan subjek penelitian menyebabkan perolehan akhir yang salah. Hal ini sesuai dengan penelitian Tambychik \& Meerah (2010) menjelaskan bahwa ketidakmampuan siswa menggunakan konsep yang benar ketika menyelesaikan masalah menyebabkan jawaban yang salah. Lebih lanjut, Hidayati, Subanji, \& Sisworo (2017) mengungkapkan bahwa penyebab dari jawaban akhir yang salah dikarenakan tidak munculnya konsep matematika yang dibutuhkan. Widdiharto (2008) menyatakan bahwa pengerjaan soal yang asal-asalan saat menyelesaikan suatu masalah menyebabkan kesalahan pada proses pekerjaannya. Wu \& Adams (2006) juga menyatakan bahwa siswa yang dapat memahami konsep sekalipun akan gagal dalam menyelesaikan suatu masalah jika tidak teliti. Brown \& Quinn (2006) menambahkan bahwa kesalahan siswa dalam mengerjakan soal karena siswa terburu-buru atau tanpa melihat lagi jawaban mereka.

Tahapan terakhir adalah memeriksa jawaban yang didapatkan. Kegiatan yang dilakukan adalah menyimpulkan hasil penyelesaian menggunakan teks tertulis berdasarkan hasil perhitungan yang diperoleh. Kemudian pada tahapan ini siswa memeriksa kebenaran jawabannya dan melihat kesesuaian hasil yang diperoleh dengan masalah awal. Namun, subjek penelitian tidak melaksanakan pengecekan jawaban yang telah didapatkan. Selain itu ketika diwawancarai subjek penelitian tidak mengerti bagaimana cara untuk melakukan pengecekan atas jawaban yang didapatkan (Tarmizi, 2010). Hal ini sesuai dengan penelitian (Egodawatte, 2009) yang mengungkapkan kebanyakan kesalahan yang terjadi ketika menyelesaikan masalah aljabar terletak pada kegiatan pengecekan kembali jawaban yang diperoleh. Berdasarkan hasil penelitian, S1 melakukan kesalahan representasi simbol dengan tidak menuliskan kesimpulan jawaban. Pada soal nomor 1 , S1 menuliskan $W=06.15+35=06.50+$ $30 \mathrm{mnt}=06.80=07.20$. Pada persoalan nomor dua, $\mathrm{S} 1$ menulis hasil akhir $x=6$. Hal ini sesuai dengan penelitian Musdhalifah et al., (2013) menyatakan bahwa siswa berkemampuan tinggi melakukan kesalahan pada tahapan memeriksa hasil yang diperoleh karena tidak menulis kesimpulan hasil jawaban.

\section{SIMPULAN}

Berdasarkan uraian kesalahan-kesalahan representasi yang dijabarkan maka dapat disimpulkan bahwa siswa berkemampuan matematika tinggi melakukan kesalahan representasi visual dan verbal pada tahapan memahami masalah. Kesalahan representasi verbal yang dilakukan adalahtidak menuliskan informasi yang diketahui yaitu bus istirahat satu kali selama 35 menit. Sedangkan kesalahan representasi visual yang dilakukan adalah ketika menggambar tabel. Dalam tabel tersebut subjek menuliskan pada baris pertama kolom "hari" adalah 20 dan kolom "pekerja" adalah 20. Pada baris kedua menuliskan pada kolom "hari" adalah 6 dan kolom "pekerja" adalah $x$. Sementara itu, pada tahap merencanakan penyelesaian, siswa melakukan kesalahan representasi simbol. Kesalahan tersebut yaitu ketika menulis rumus jarak sebenarnya kota Nganjuk dan Banyuwangi dan penulisan persamaan dalam menentukan pekerja yang dibutuhkan yaitu $20 \times x=20+6$. Kemudian pada tahapan melaksanakan rencana penyelesaian, siswa melakukan kesalahan representasi simbol. Kesalahan tersebut dilakukan ketika siswa menuliskan jarak kota Nganjuk dan Banyuwangi pada peta dalam perhitungan mencari jarak sebenarnya kota Nganjuk dan Banyuwangi dan penulisan kecepatan rata-rata bus dalam perhitungan mencari jarak tempuh bus. Selanjutnya pada tahap memeriksa hasil yang diperoleh melakukan kesalahan representasi simbol. Kesalahan representasi simbol yang dilakukan adalah tidak menyimpulkan hasil akhir jawaban. 
Penelitian ini adalah penelitian yang mendeskripsikan tentang jenis-jenis kesalahan representasi yang dilakukan siswa dalam menyelesaikan masalah perbandingan. Berdasarkan hasil pembahasan, peneliti memberikan saran bahwa jenis-jenis kesalahan representasi yang tampak pada penelitian ini mungkin tidak mencakup semua jenis kesalahan representasi yang dilakukan siswa. Maka penelitian yang terkait dengan analisis jenis kesalahan representasi siswa perlu dikembangkan. Selain itu, Seorang guru sebaiknya membiasakan siswa untuk memeriksa kembali jawabannya misalnya dalam proses perhitungan dan pemilihan strategi yang digunakan dalam menyelesaikan suatu masalah.

\section{DAFTAR RUJUKAN}

Arnidha, Y. (2015). Analisis Kesalahan Siswa dalam Menyelesaikan Soal Operasi Hitung Bilangan Cacah. Journal E-DuMath, $1(1), 52-63$.

Baraké, F., El-Rouadi, N., \& Musharrafieh, J. (2015). Problem Solving at the Middle School Level: A Comparison of Different Strategies. Journal of Education and Learning, 4(3), 62-70.

Baxter, J. A., \& Williams, S. (2010). Social and analytic scaffolding in middle school mathematics: Managing the dilemma of telling. Journal of Mathematics Teacher Education, 13(1), 7-26.

Brown, G., \& Quinn, R. (2006). Algebra Students' Difficulty with Fractions: An Error Analysis. Australian Mathematics Teacher, 62(4), 28-40.

Buaddin, H. (2015). Penggunaan Scaffolding untuk Mengatasi Kesulitan Menyelesaikan Masalah Matematika. Jurnal APOTEMA, 1(1), 88-98.

Castellanos, J. L. V., Castro, E., \& Gutiérrez, J. (2009). Representations in Problem Solving: A Case Study with Optimization Problems. Electronic Journal of Research in Educational Psychology, 7(17), 279-308.

Cockcroft, W. H. (1982). Mathematics Counts: Report of The Committee of Enquiry into the Teaching of Mathematics in Schools. London: HMSO.

Cresswell, J. W. (2012). Educational Research: Planning, Conducting, and Evaluating Quantitative and Qualitative Research (Fourth Edition). Boston: Pearson Education.

Egodawatte, G. (2009). Is Algebra Really Difficult for All Students ? Acta Didactica Napocensia, 2(4), 101-106.

Fadillah, S. (2010). Kemampuan Pemecahan Masalah Matematis dalam Pembelajaran Matematika. Prosiding Seminar Nasional Penelitian, Pendidikan Dan Penerapan MIPA, Fakultas MIPA, Universitas Negeri Yogyakarta, 553-338.

Goldin, G., \& Steingold, N. (2001). System of Representations and the Development of Mathematical Concepts. USA: NCTM.

Hidayati, V. R., Subanji, \& Sisworo. (2017). Analisis Kesalahan Siswa Smp Dalam Menyelesaikan Masalah Matematika Pisa Pada Tahapan Penyelesaian Blumleiss. Prosiding Seminar Nasional Pendidikan Matematika 2017, 108-119.

Hwang, W. Y., Chen, N. S., Dung, J. J., \& Yang, Y. L. (2007). Multiple Representation Skills and Creativity Effects on Mathematical Problem Solving using a Multimedia Whiteboard System. Educational Technology \& Society, 10, 191-212.

Jupri, A., Drijvers, P., \& Van den Heuvel-Panhuizen, M. (2014). Student Difficulties in Solving Equations from an Operational and a Structural Perspective. International Electronic Journal of Mathematics Education, 9(1-2), 39-55.

Kalathil, R. R., \& Sherin, M. G. (2000). Role of Students' Representations in the Mathematics Classroom. Fourth International Conference of the Learning Sciences, 27-28.

Lannin, J. K., Barker, D. D., \& Townsend, B. E. (2007). How students view the general nature of their errors. Educational Studies in Mathematics, 66(1), 43-59. https://doi.org/10.1007/s10649-006-9067-8

Liang, S. (2013). An Example of Coherent Mathematics Lesson. Universal Journal of Educational Research, 1(2), 57-64.

Matic, L. J. (2014). Mathematical Knowledge of Non-mathematics Students and Their Beliefs about Mathematics. 9(1), $13-24$.

Mudzakir, H. S. (2006). Strategi Pembelajaran Think-Talk-Write untuk Meningkatkan Kemampuan Representasi Matematik Beragam Siswa SMP. Tesis tidak diterbitkan. Universitas Pendidikan Indonesia, Bandung.

Musdhalifah, U., Sutinah, \& Kurniasari, I. (2013). Analisis Kesalahan Siswa Kelas VII dalam Memecahkan Masalah Non Rutin yang Terkait dengan Bilangan Bulat Berdasarkan Tingkat Kemampuan matematika di SMP N 31 Surabaya. Jurnal Pendidikan, 1(1), 1-6. (Online). http://jurnalmahasiswa.unesa.ac.id/index.php/mathedunesa/article/view/3905, diakses tanggal 24 September 2019.

NCTM. (2000). Principles and Standards for School Mathematics. Reston: NCTM.

Pantziara, M., Gagatsis, A., \& Elia, I. (2009). Using Diagrams as Tools for the Solution of Non-Routine Mathematical Problems. 39-60.

Prakitipong, N., \& Nakamura, S. (2006). Analysis of Mathematics Performance of Grade Five Students in Thailand Using Newman Procedure. In Journal of International Cooperation in Education (Vol. 9).

Rahayu, A., Muhsetyo, G., \& Rahardjo, S. (2016). Analisis Kesalahan Pemahaman Siswa dalam Menyelesaikan Soal Cerita Materi Sistem Persamaan Linear Dua Variabel pada SIswa SMP Ar-Rohmah. Makalah disajikan dalam Prosiding Seminar Nasional Pendidikan Matematika dengan tema "Pengembangan 4C's dalam Pembelajaran Matematika: Sebuah Tatangan Pengembangan Kurikulum Matematika”, pada tanggal 28 Mei 2016 di Program Studi Pendidikan Matematika Universitas Negeri Malang.

Rindyana, B. S. B. (2012). Analisis Kesalahan Siswa dalam Menyelesaikan Soal Cerita Matematika Materi Sistem Persamaan Linier Dua Variabel Berdasarkan Analisis Newman. Tesis tidak diterbitkan. Universitas Negeri Malang, Malang. 
Rohmah, M., \& Sutiarso, S. (2018). Analysis Problem Solving in Mathematical Using Theory Newman. Eurasia Journal of Mathematics, Science and Tecnology Education., 14(2), 671-681.

Shreyar, S., Zolkower, B., \& Pérez, S. (2010). Thinking a Loud Together: A Teacher's Semiotic Mediation of a Whole-Class Conversation about Percents. In Educational Studies in Mathematics (Vol. 73).

Sugiyono. (2012). Metode Penelitan Kuantitatif, Kualitatif, dan R \& D. Bandung: Alfabeta.

Supandi, S., Waluya, S. B., Rochmad, R., Suyitno, H., \& Dewi, K. (2018). Think-Talk-Write Model for Improving Students' Abilities in Mathematical Representation. International Journal of Instruction, 11(3), 77-90.

Tambychik, T., \& Meerah, T. S. M. (2010). Students' Difficulties in Mathematics Problem-Solving: What do they say? Procedia - Social and Behavioral Sciences, 8, 142-151.

Tarmizi, R. A. (2010). Visualizing Students' Difficulties in Learning Calculus. Procedia - Social and Behavioral Sciences, 8 , $377-383$.

Widdiharto, R. (2008). Diagnosis Kesulitan Belajar Matematika SMP dan Alternatif Proses Remedinya. Yogyakarta: Departemen Pendidikan Nasional.

Widodo, S. A. (2013). Analisis Kesalahan dalam Pemecahan Masalah Divergen Tipe Membuktikan pada Mahasiswa Matematika. Jurnal Pendidikan dan Pengajaran, 46(2), 106-113.

Wu, M., \& Adams, R. J. (2006). Modelling Mathematics Problem Solving Item Responses Using a Multidimensional IRT model. Mathematics Education Research Journal, 18(2), 93-113. 